\title{
Comparison of populations of Melanagromyza sojae and Liriomyza sativae associated with Mung bean Vigna radiata (Linn.) Wilczek grown in Biratnagar, eastern Nepal
}

\author{
Moon Thapa \\ Department of Biology, Birat Campus, Biratnagar, Nepal \\ E-mail:niwaj@yahoo.com
}

Key words: Leaf miners, Diptera, Agromyzidae, legume host, Nepal

\begin{abstract}
Agromyzidae are popularly known as leaf miners. The larvae of these flies may form external stem mines, bore internally in stem of herbaceous plants or in the cambium of trees or feed on roots or flower heads. Approximately, there are 2750 described species with many species awaiting formal description.
\end{abstract}

Research was carried out at various times to rear these flies at various places of Eastern Nepal. Those studies showed that major or key pest which causes damage in the absence of effective control measure is stem fly Melanagromyza sojae (Zehntner). Thapa (1997, 2000) has reported 5 species from this host plant. These species were Chromatomyia horticola (Goureau), Liriomyza sativa Blanchard, Ophiomya centrosematis (de Meijere), Melanagromyza sojae (Zehntner), Melanagromyza hibisci Spencer from Biratnagar, eastern Nepal.

Thapa (1997) again reported 8 species of economically important agromyzid flies from Eastern terai region, Biratnagar Nepal and discussed their range of host plants. Further, Thapa (2000) reared and described 13 species of agromyzid flies belonging to 5 genera by male genitalia preparation and surveyed and determined 100 species of host plants belonging to 81 genera and 23 families from Eastern Nepal. Poudyal (2003) has reported 4 species of agromyzid flies.

Mung bean Vingna radiate (L.) Wilczek var. K851 was at three locations A, B, C of Biratnagar (Lat. $26^{\circ} 20^{\prime} \mathrm{N}$; Long. $87^{\circ} 16^{\prime} \mathrm{E}$; Alt. $72 \mathrm{msl}$ ) by randomized block design. Fields A and $\mathrm{B}$ were situated at Biratnagar 18, P.G. Campus compound and third field $\mathrm{C}$ was situated at Biratnagar 17. Each field consisted of 66 plots. The beds/plots were numbered serially and $10 \mathrm{~g}$ of mung bean seeds was sown in each bed of the plots.

First sampling was done when the plant was between 10-15 days old. Five to ten plants were taken from each bed and were kept in polythene bags. Bags were sealed. Identification of bags was done with sticker, indicating field, plot number, sample number and date of collection of plants. The bags were checked near by a light source to see whether the flies emerged or not. The emerged flies were collected in glass vials and were properly labelled. The same procedure was repeated in all the three fields. In general, six species of flies belonging to 3 genera Menanogramyza, Ophiomyia and Liriomyza were reared. About 500 male flies were dissected and equal number of genitalia slides were made. Comparision of the populations of two species $M$. sojae and L. sativae was done using t-test (Tab. 1). 
Table 1. The reared populations of M. sojae and L. sativae in three fields.

\begin{tabular}{lcccccccccccc}
\hline & \multicolumn{3}{c}{ Field A } & \multicolumn{1}{c}{ Field B } & \multicolumn{5}{c}{ Field C } \\
\hline Sample Number & 1 & 2 & 3 & 4 & 1 & 2 & 3 & 4 & 1 & 2 & 3 & 4 \\
\hline M. sojae reared & 51 & 26 & 1 & 4 & 34 & 33 & 3 & 1 & 104 & 7 & 10 & 1 \\
L. sativae reared & 16 & 7 & 0 & 0 & 3 & 1 & 0 & 0 & 25 & 1 & 0 & 0 \\
\hline
\end{tabular}

Calculated value of $\mathrm{t}$ for three different fields was $\mathrm{t}_{\mathrm{cal}}=1.21,1.83$ and 0.947 , respectively. As the calculated value of $t$ was fund to be less than its critical value at $5 \%$ level for $6 \mathrm{~d}$.f ( $\mathrm{t}$ $0.05,6=2.477$ ), the null hypothesis was accepted i.e. there was no significant difference between mean populations of $M$. sojae and $L$. sativae reared from four different samples.

Thanks are due to the Head, Department of Zoology, P.G. Campus, T.U., Biratnagar for facilities.

\section{References}

Poudyal, B. 2003. Species determination and some ecological studies of agromyzid flies associated with some commonly cultivated leguminous crops of Jhapa district, Eastern Nepal. M.Sc. Thesis, Dept of Zoology, P.G. Campus, T.U., Biratnagar, Nepal. 87p.

Thapa, M. 2005. Study of field population and diversity of Leaf miners (Diptera: Agromyaidae) infesting Mung bean Vigna radiata (Linn.) Wilczek grown in Biratnagar eastern Nepal. M.Sc. Thesis, Dept. of Zoology, P.G. Campus, T.U., Biratnagar, Nepal. 226p.

Thapa, R.B. 1991. Survey and taxonomic studies on the Agromyzid flies associated with leguminious hosts at Pantnagar in the Northern India. Ph.D. Thesis, G.B. Pant University of Agriculture and Technology, Pantnagar, India. 420p.

Thapa, R.B. 1997. Survey of agromyzid flies (Leaf miners) associated with economically important crops and weed in and around Biratnagar, eastern Nepal. Research report, Research Division, Tribhuvan University, Kirtipur. 15p.

Thapa, R.B. 2000. Survey of agromyzid host range in Morang district, eastern Nepal. Report, UGC, Nepal. 